\title{
Production of Aruana guinea grass subjected to different cutting severities and nitrogen fertilization
}

\author{
ALESSANDRA A. GIACOMINI, KARINA BATISTA, MARIA T. COLOZZA, LUCIANA GERDES, \\ WALDSSIMILER T. MATTOS, IVANI P. OTSUK, FLAVIA M.A. GIMENES AND LINDA M. PREMAZZI
}

Instituto de Zootecnia, Nova Odessa, SP, Brazil. www.iz.sp.gov.br

Keywords: Cutting height, Panicum maximum, morphological composition, forage accumulation.

\section{Introduction}

Aruana guinea grass (Panicum maximum cv. Aruana) is widely used as pasture for sheep, which are extremely susceptible to infestation by larvae of gastrointestinal parasites in tropical pasture-based systems (Zanini et al. 2012). One way to mitigate this problem, and consequently reduce the need for use of anthelmintics, is to manage pastures with post-grazing height low enough to ensure sunlight reaches the base of tussocks. This will aid in killing larvae and controlling their development, without jeopardizing canopy regrowth and persistence. The pre-grazing sward height recommended for Aruana guinea grass is $30 \mathrm{~cm}$, when the canopy intercepts $95 \%$ of the incident light, with post-grazing height at $15 \mathrm{~cm}$ (Zanini et al. 2012). As cutting severity and nitrogen (N) fertilization cause morphological and physiological adaptations in individual plants - altering the production of forage grasses - the objective of this study was to evaluate the accumulation of morphological components of Aruana guinea grass subjected to different cutting severities and $\mathrm{N}$ fertilization.

\section{Methods}

Cylinders (15 $\mathrm{cm}$ diameter x $20 \mathrm{~cm}$ deep) of undisturbed soil + plant samples (Mattos and Monteiro 2003) were collected from an Aruana guinea grass pasture established in 2001 and used for sheep grazing. The material (soil + plant) collected was stored in ceramic pots and placed in a greenhouse. Treatments corresponded to 4 nitrogen $(\mathrm{N})$ rates $\left(50,100,150\right.$ and $\left.200 \mathrm{mg} / \mathrm{dm}^{3}\right) \mathrm{com}-$ bined with 2 defoliation severities $(10$ and $15 \mathrm{~cm}$

Correspondence: Alessandra A. Giacomini, Instituto de Zootecnia, Rua Heitor Penteado 56, CP 60, Nova Odessa CEP 13460-000, SP, Brazil.

Email: giacomini@iz.sp.gov.br height), in a complete randomized block design with 4 replications in a $4 \times 2$ factorial arrangement. The experiment was conducted from November 2012 to March 2013. After a 20-day adjustment period, the first cut at 10 and $15 \mathrm{~cm}$ height and application of $\mathrm{N}$ were carried out. Further cuts at 10 or $15 \mathrm{~cm}$ were made when the pastures reached $30 \mathrm{~cm}$ height. After each cut, the collected material was separated into leaves (leaf laminae), stems (stems + leaf sheaths) and dead material, then dried in a forced-draught oven at $65{ }^{\circ} \mathrm{C}$ until reaching constant mass before weighing. The results were used to calculate the accumulation of each component above the cutting heights $(10$ and $15 \mathrm{~cm})$ on each occasion and to determine total production of each morphological component during the period evaluated. Data were subjected to analysis of variance using the GLM procedure of the statistical package $\mathrm{SAS}^{\circledR}$ (Statistical Analysis System, version 9.3), using a 5\% significance level. The $\mathrm{F}$ test was used to compare means of cutting heights, and for the $\mathrm{N}$ rates regression analysis (linear and quadratic effects) was used. For analysis of leaf accumulation and leaf:stem ratio, data were log-transformed and for stem accumulation, data were square root-transformed.

\section{Results and Discussion}

Dry matter accumulation per pot of leaf, stem and dead material of Aruana guinea grass varied according to cutting height and $\mathrm{N}$ rate (Figure 1). Accumulation of leaf material increased significantly as the level of applied $\mathrm{N}$ increased, but there was no consistent effect of cutting height on leaf yield. The regression analysis showed a linear response to $\mathrm{N}$ rate for accumulation of leaf material $\left(\mathrm{Y}=-0.9250+0.08695 \mathrm{~N} ; \mathrm{R}^{2}=0.99\right)$ across the cutting heights. Both stem and dead matter accumulation were higher at $10 \mathrm{~cm}$ cutting height than at $15 \mathrm{~cm}$ for all $\mathrm{N}$ rates. Leaf:stem ratio varied between cutting heights for all except the $200 \mathrm{mg} / \mathrm{dm}^{3}$ treatment. With regard to stem accumulation per pot, regression 
analysis showed a quadratic effect in the average of cutting heights $\left(\mathrm{Y}=0.84375-0.0127 \mathrm{~N}+0.00013 \mathrm{~N}^{2}\right.$, $\left.\mathrm{R}^{2}=0.98\right)$; the smallest forage accumulation was observed with $50 \mathrm{mg} / \mathrm{dm}^{3}$ of $\mathrm{N}$. No effect of $\mathrm{N}$ rate on dead material accumulation was observed.

According to Zanini et al. (2012), managing Aruana guinea grass swards with grazing at $95 \%$ incident light interception (30 cm high) and having it grazed to $15 \mathrm{~cm}$ post-grazing height, ensures greater rates of dry mass accumulation and better control of stem elongation. However, our results showed that there seems to be no difference between $10 \mathrm{~cm}$ and $15 \mathrm{~cm}$ cutting height in terms of leaf accumulation per pot. Cutting to $10 \mathrm{~cm}$ height can have an additional advantage of allowing sunlight to penetrate to the base of tussocks, restricting the development of gastrointestinal larvae.

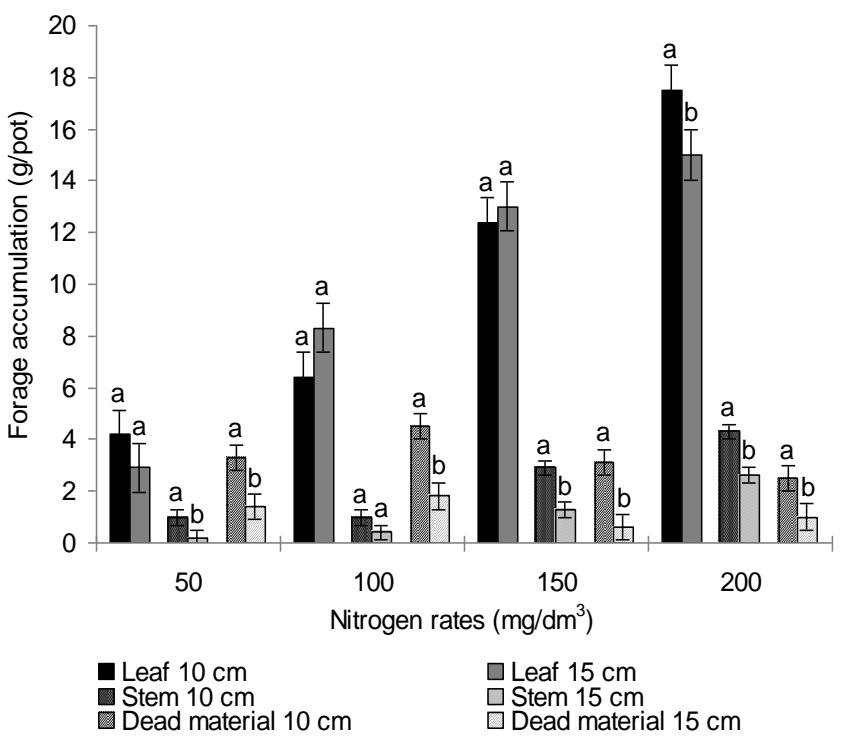

Figure 1. Accumulation of morphological components in Aruana guinea grass subjected to 2 cutting heights and 4 nitrogen rates. Different letters on columns indicate significant differences $(\mathrm{P}<0.05)$ between morphological component means within nitrogen rates. Vertical bars correspond to standard error of the mean.
At all fertilizer levels, the accumulation of both stem and dead material was higher at the $10 \mathrm{~cm}$ cutting height. Therefore, when using $\mathrm{N}$ fertilizer to increase productivity, it is important to adjust the frequency and severity of cuts. For the $\mathrm{N}$ application to be most effective, leaves should be harvested before they become senescent, and stem elongation should be prevented, which is common in tropical grasses from the point when the canopy intercepts more than $95 \%$ of incident light.

\section{Conclusion}

The use of $10 \mathrm{~cm}$ cutting height together with a regrowth interval that allows the canopy to reach $30 \mathrm{~cm}$ height can be used as a target in the management of Aruana guinea grass, in particular if $\mathrm{N}$ provided is adequate.

\section{Acknowledgments}

The authors thank FAPESP (Fundação de Apoio à Pesquisa do Estado de São Paulo) for funding this research.

\section{References}

Mattos WT; Monteiro FA. 2003. Produção e nutrição de capim-braquiária em função de doses de nitrogênio e enxofre. Boletim de Indústria Animal 60:1-10.

Zanini GD; Santos GT; Sbrissia AF. 2012. Frequencies and intensities of defoliation in Aruana Guineagrass swards: Accumulation and morphological composition of forage. Revista Brasileira de Zootecnia 41:905-913. 
Giacomini AA; Batista K; Colozza MT; Gerdes L; Mattos WT; Otsuk IP; Gimenes FMA; Premazzi LM. 2014. Production of Aruana guinea grass subjected to different cutting severities and nitrogen fertilization. Tropical Grasslands - Forrajes Tropicales 2:53-54.

DOI: $\underline{10.17138 / \mathrm{TGFT}(2) 53-54}$

This paper was presented at the $22^{\text {nd }}$ International Grassland Congress, Sydney, Australia, 15-19 September 2013. Its publication in Tropical Grasslands - Forrajes Tropicales is the result of a co-publication agreement with the IGC Continuing Committee. Except for adjustments to the journal's style and format, the text is essentially the same as that published in: Michalk LD; Millar GD; Badgery WB; Broadfoot KM, eds. 2013. Revitalising Grasslands to Sustain our Communities. Proceedings of the $22^{\text {nd }}$ International Grassland Congress, Sydney, Australia, 2013. New South Wales Department of Primary Industries, Orange, NSW, Australia. p. 1526-1527. 